\title{
Influence of Divalent Cations on the Growth and Morphology of Bacillus stearothermophilus
}

\author{
By AMÁliA S. JURADO, ${ }^{1}$ AUGUSTO C. SANTANA, ${ }^{2}$ \\ MILTON S. DA COSTA ${ }^{1 *}$ AND VÍTOR M. C. MADEIRA ${ }^{1}$ \\ ${ }^{1}$ Centro de Biologia Celular, Universidade de Coimbra, 3049 Coimbra Codex, Portugal \\ ${ }^{2}$ Laboratório de Microbiologia, Faculdade de Medicina, Universidade de Coimbra, \\ 3049 Coimbra Codex, Portugal
}

(Received 29 July 1986; revised 28 October 1986)

Bacillus stearothermophilus grows within the temperature range $40-70{ }^{\circ} \mathrm{C}$ in a complex medium that contains $115 \mu \mathrm{M}-\mathrm{Ca}^{2+}$ and $95 \mu \mathrm{M}-\mathrm{Mg}^{2+}$. The addition of $\mathrm{Ca}^{2+}$ to a final concentration ranging from 2.5 to $10 \mathrm{~mm}$ stimulated growth at suboptimal and supraoptimal temperatures, extending growth above $70^{\circ} \mathrm{C}$, but had no effect on growth within the optimal temperature range. $\mathrm{Mg}^{2+}(2.5 \mathrm{~mm})$ also stimulated growth although to a lesser extent. Furthermore, $10 \mathrm{~mm}$ $\mathrm{Mg}^{2+}$ inhibited growth at temperatures higher than $65^{\circ} \mathrm{C}$. This inhibitory effect was relieved by the addition of $2.5 \mathrm{mM}-\mathrm{Ca}^{2+} . \mathrm{Sr}^{2+}(10 \mathrm{mM})$, which often behaves as a $\mathrm{Ca}^{2+}$ analogue in biological systems, strongly inhibited growth and produced gross morphological alterations in the cells. The inhibitory effect of $\mathrm{Sr}^{2+}$ could also be relieved by addition of $\mathrm{Ca}^{2+}$.

\section{INTRODUCTION}

Several mechanisms have been proposed to explain the ability of thermophilic microorganisms to grow at temperatures at which mesophilic (prokaryotic and eukaryotic) organisms can not survive. The capacity of thermophiles to grow at higher temperatures than mesophiles is generally regarded as a consequence of their ability to synthesize cell components with increased heat stability (Friedman, 1968; Irwin et al., 1973; Singleton \& Amelunxen, 1973). Several investigations emphasize the importance of membrane stability in relation to heat tolerance; Brock (1967) has suggested that the molecular mechanism of thermophily is possibly more related to the function and stability of the membrane than to any special macromolecule. The capacity of thermophiles to control the physical properties of the cytoplasmic membrane by changing its lipid composition in response to temperature changes has been supported by the work of several authors (Daron, 1970; Ray et al., 1971 a, b; Weerkamp \& Heinen, 1972; Hasegawa et al., 1980). Ions, especially divalent cations also have a role in thermostability (Ljunger, 1970; Stähl \& Ljunger, 1976; Stähl, 1978; Mosley et al., 1976). Ljunger (1970) has proposed that $\mathrm{Ca}^{2+}$, accumulated inside the cell by active transport, is required for the thermostability of cell proteins. However, Mosley et al. (1976) suggested that divalent cations increase membrane stability by the formation of cation-bridges between the anionic groups of the acidic membrane phospholipids.

The present study reports the effect of the divalent cations $\mathrm{Ca}^{2+}, \mathrm{Mg}^{2+}$ and $\mathrm{Sr}^{2+}$ on growth and morphology of Bacillus stearothermophilus at different temperatures.

\section{METHODS}

Organism and culture conditions. The strain of Bacillus stearothermophilus used was isolated from discs impregnated with spores supplied by Mast Laboratories, UK (lot no. 8879). Stock cultures were maintained at $4{ }^{\circ} \mathrm{C}$ on tryptic soy agar (Difco) slants.

Cultures were grown in dilute L-broth containing $5.0 \mathrm{~g}$ D-glucose, $5.0 \mathrm{~g}$ tryptone (Difco), $2.5 \mathrm{~g}$ yeast extract (Difco), $1.25 \mathrm{~g} \mathrm{NaCl}$ and 0.024 $\mathrm{g} \mathrm{L}$-cystine. $\mathrm{HCl}$ in 11 water (final $\mathrm{pH} 7.0-7.2$ ); $15 \mathrm{~g} \mathrm{Difco-Agar} \mathrm{was} \mathrm{added} \mathrm{for} \mathrm{solid}$ 
medium. Concentrated stock solutions of $\mathrm{CaCl}_{2}, \mathrm{MgCl}_{2}$ and $\mathrm{SrCl}_{2}$ (nominally $1 \mathrm{M}$ ) were sterilized by filtration and added to the growth medium to give the desired final cation concentrations.

Liquid cultures were started with an early stationary phase inoculum from dilute L-broth without added cations, grown within the optimal temperature range, to give an initial $\mathrm{OD}_{610}$ of about 0.03 . Cultures were grown in $250 \mathrm{ml}$ Erlenmeyer flasks containing $50 \mathrm{ml}$ medium shaken at 130 r.p.m. in a New Brunswick (RW-650) water bath shaker; growth was measured as optical density, using a Varian Techtron spectrophotometer at $610 \mathrm{~nm}$, or by counting c.f.u. on agar plates.

Analytical methods. Magnesium and calcium were determined in the control medium without added ions and in the stock solutions by atomic absorption spectrometry using a Perkin-Elmer model 305 spectrometer. Interference by phosphates was controlled by including $0.5 \% \mathrm{La}^{3+}$ in standards and samples.

Electron microscopy. Broth cultures collected by centrifugation $\left(6000 \mathrm{~g}\right.$ for $10 \mathrm{~min}$ at $4{ }^{\circ} \mathrm{C}$ ) were pre-fixed in $2.5 \%$ (w/v) glutaraldehyde buffered with cacodylate $(0.2 \mathrm{M}, \mathrm{pH} 7.2)$ supplemented with $10 \mathrm{~mm}-\mathrm{CaCl}_{2}$, for $1 \mathrm{~h}$ at room temperature (Silva, 1984). The cells were then fixed overnight in $1 \%(\mathrm{w} / \mathrm{v}) \mathrm{OsO}_{4}$ buffered with veronal/acetate (Ryter \& Kellenberger, 1958) pH 6.2, supplemented with $10 \mathrm{mM}-\mathrm{CaCl}_{2}$. Post-fixation was done with $0 \cdot 5 \%$ (w/v) uranyl acetate in water for $1 \mathrm{~h}$. After dehydration, the material was embedded in Epon resin and ultrathin sections were obtained. The sections were contrasted with lead citrate according to Venable \& Coggeshall (1965) and viewed in a Joel $100 \mathrm{~S}$ electron microscope at $80 \mathrm{kV}$.

\section{RESULTS}

\section{Effect of divalent cations on growth at different temperatures}

The strain of $B$. stearothermophilus used in this study grew in the temperature range $40-70{ }^{\circ} \mathrm{C}$ in a complex medium (dilute L-broth) with endogenous concentrations of $0.115 \mathrm{~mm}-\mathrm{Ca}^{2+}$ and $0.095 \mathrm{mM}-\mathrm{Mg}^{2+}$ (control medium).

At supraoptimal temperatures (above $65^{\circ} \mathrm{C}$ ), growth in control medium was characterized by a progressively longer lag period, a lower specific growth rate and a lower final culture density. This trend could be relieved by addition of $\mathrm{Ca}^{2+}$ (Fig. 1). The stimulatory effect of $\mathrm{Ca}^{2+}$ on growth was concentration dependent between 0.25 and $2.5 \mathrm{mM}$; higher concentrations of $\mathrm{Ca}^{2+}$ (up to $10 \mathrm{mM}$ ) had no additional effect on growth. The experiments performed at $70^{\circ} \mathrm{C}$ also indicated that growth in the control medium was erratic, occurring in some experiments but not in others, probably reflecting slight changes in the temperature of incubation.

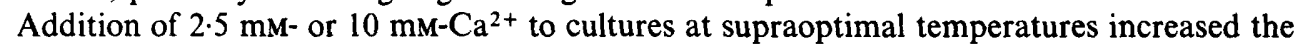
growth rate and permitted significant growth at temperatures up to $72^{\circ} \mathrm{C}$ (Table 1). In contrast to this effect at supraoptimal temperatures, no effect was observed between 55 and $65^{\circ} \mathrm{C}$. $\mathrm{Ca}^{2+}$ also stimulated the growth rate at suboptimal temperatures, but to a lesser extent than was observed at supraoptimal temperatures.

$\mathrm{Mg}^{2+}$ at a concentration of $2.5 \mathrm{~mm}$ stimulated growth at suboptimal and supraoptimal temperatures, but to a lesser extent than $\mathrm{Ca}^{2+}$. A slight stimulatory effect of $2.5 \mathrm{mM}-\mathrm{Mg}^{2+}$ was observed between 68 and $71{ }^{\circ} \mathrm{C}$, but at $72^{\circ} \mathrm{C}$ this concentration of $\mathrm{Mg}^{2+}$, in contrast to $\mathrm{Ca}^{2+}$, had no detectable effect on growth within the experimental period. At the suboptimal temperature of $45^{\circ} \mathrm{C}, 2.5 \mathrm{~mm}$ - and $10 \mathrm{~mm}-\mathrm{Mg}^{2+}$ also caused a slight increase in growth rate but, as in the case of $\mathrm{Ca}^{2+}$, no effect was detected between 55 and $65^{\circ} \mathrm{C}$. In contrast to $10 \mathrm{mM}-\mathrm{Ca}^{2+}$, which stimulated growth above the optimal temperature range, $10 \mathrm{mM}-\mathrm{Mg}^{2+}$ had a profound inhibitory effect at temperatures above $65^{\circ} \mathrm{C}$ (Table 1). The inhibition of growth induced by $10 \mathrm{mM}-\mathrm{Mg}^{2+}$ was reversed when $2.5 \mathrm{mM}$ - or $10 \mathrm{mM}-\mathrm{Ca}^{2+}$ was auded to the culture, resulting in a similar growth rate to the $2.5 \mathrm{mM}$ - or $10 \mathrm{mM}^{-\mathrm{Ca}^{2+}}$ control cultures (Fig. 2).

The addition of low concentrations of $\mathrm{Sr}^{2+}(0.25$ and $0.5 \mathrm{mM})$ had no effect on growth, while $2.5 \mathrm{mM}-$ and $10 \mathrm{mM}^{-} \mathrm{Sr}^{2+}$ had a generalized inhibitory effect on growth at temperatures above $60{ }^{\circ} \mathrm{C}$. The inhibition of growth induced by $\mathrm{Sr}^{2+}$ was reflected in a decrease both in the growth rate (Table 1) and in the final cell density. Often, the cultures with $2.5 \mathrm{mM}_{-} \mathrm{Sr}^{2+}$ had a high initial growth rate followed by a lower rate as growth proceeded. The inhibitory effect of $10 \mathrm{mM}-\mathrm{Sr}^{2+}$ was more profound and at low temperatures (i.e. $60^{\circ} \mathrm{C}$ ) was characterized by a fairly high initial growth rate followed by an abrupt cessation of growth and a decrease in the number of c.f.u. (Fig. $3 a$ ). At higher temperatures, growth in medium with $10 \mathrm{mM}^{-S_{r}{ }^{2+}}$ was initially noticeable, but ceased thereafter (Fig. $3 b$ ). The inhibitory effect of $10 \mathrm{mM}-\mathrm{Sr}^{2+}$ on growth could be relieved, as for $\mathrm{Mg}^{2+}$-inhibited cultures, by the addition of $2.5 \mathrm{mM}^{-\mathrm{Ca}^{2+}}$ for at least $2 \mathrm{~h}$ after inoculation of the cells. 


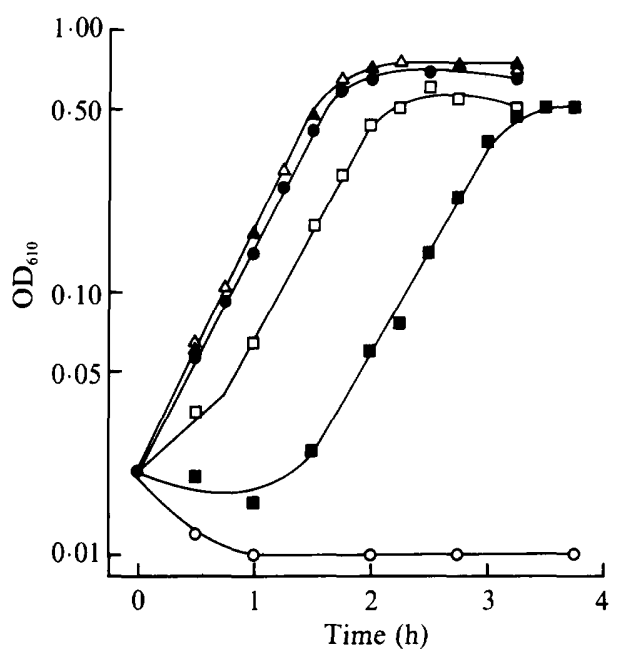

Fig. 1

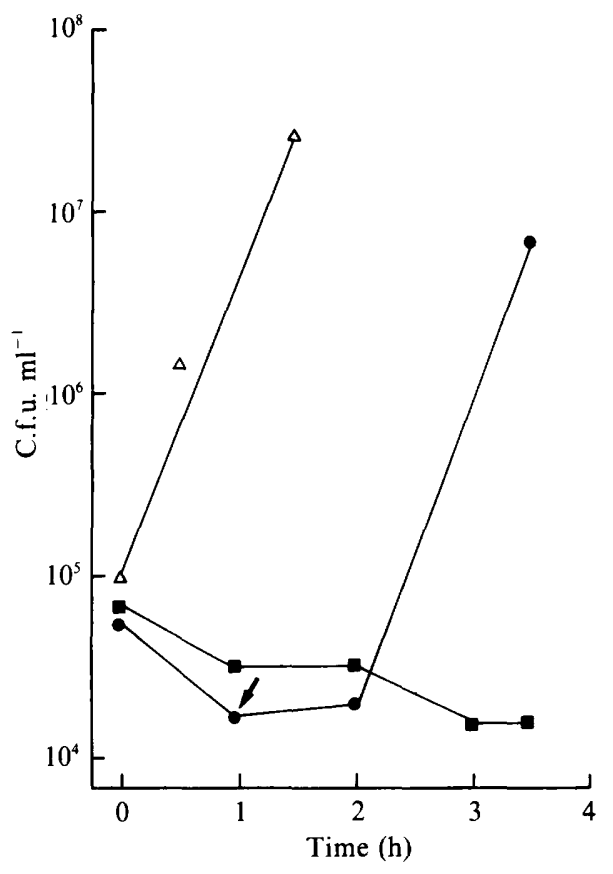

Fig. 2

Fig. 1. Effect of $\mathrm{Ca}^{2+}$ addition on the growth of $B$. stearothermophilus at $70^{\circ} \mathrm{C}$ in control medium (O) and media containing $\mathrm{Ca}^{2+}$ at a final concentration of $0.25 \mathrm{mM}(\square), 1.0 \mathrm{mM}(\square), 2.5 \mathrm{mM}(\triangle), 5 \mathrm{mM}(\triangle)$ and $10 \mathrm{~mm}(\boldsymbol{A})$. The results shown are typical of those obtained in three separate experiments.

Fig. 2. Effect of $\mathrm{Ca}^{2+}$ addition to cultures of $B$. stearothermophilus inhibited by $10 \mathrm{mM}-\mathrm{Mg}^{2+}$ at $71^{\circ} \mathrm{C}$. Growth was measured by determining the number of c.f.u. in media containing $2.5 \mathrm{mM}-\mathrm{Ca}^{2+}(\triangle), 10$ $\mathrm{mm}-\mathrm{Mg}^{2+}(\boldsymbol{\square})$, and $10 \mathrm{~mm}-\mathrm{Mg}^{2+}$ to which $2.5 \mathrm{~mm}-\mathrm{Ca}^{2+}$ was added (arrow) $1 \mathrm{~h}$ after inoculation $(O)$. The results shown are typical of those obtained in two separate experiments.

Table 1. Specific growth rates $\left(h^{-1}\right)$ of B. stearothermophilus in dilute L-broth and in the same medium supplemented with $\mathrm{Ca}^{2+}, \mathrm{Mg}^{2+}$ or $\mathrm{Sr}^{2+}$

Growth temp. $\left({ }^{\circ} \mathrm{C}\right)$

45

50

55

60

65

68

70

71

72

73

Specific growth rate* $(\mu)$ in dilute L-broth with:

\begin{tabular}{|c|c|c|c|}
\hline $\begin{array}{l}\text { No added } \\
\text { cations }\end{array}$ & $10 \mathrm{~mm}-\mathrm{Ca}^{2+}$ & $10 \mathrm{~mm}-\mathrm{Mg}^{2+}$ & $10 \mathrm{mM}^{-\mathrm{Sr}^{2+}}$ \\
\hline $0.15 \pm 0.07$ & 0.58 & 0.59 & ND \\
\hline $1.24 \pm 0.02(2)$ & $1.47 \pm 0.10(2)$ & $1.35 \pm 0.07(2)$ & $1 \cdot 46$ \\
\hline $2.32 \pm 0.02(2)$ & $2.44 \pm 0.06(2)$ & $2.35 \pm 0.11(2)$ & $2 \cdot 22 \quad(1)$ \\
\hline $2.92 \pm 0.22(7)$ & $3.04 \pm 0.28(2)$ & $3.15 \pm 0.06(2)$ & $2.25 \pm 0.13(4)$ \\
\hline $2.91 \pm 0.20(5)$ & $3.05 \pm 0.05(3)$ & $2.87 \pm 0.06(3)$ & $1.79 \pm 0.00(2)$ \\
\hline $2.58 \pm 0.21(5)$ & $2.70 \pm 0.33(2)$ & $1.77 \pm 0.18(3)$ & $1.86 \pm 0.55(5)$ \\
\hline 0.0 & & 0.0 & 0.0 \\
\hline $1.04 \pm 0.48(10)$ & $2 \cdot 10 \pm 0.17(8)$ & $0.58 \pm 0.13(2)$ & $0 \cdot 26$ \\
\hline $0.0 \quad(17) \ddagger$ & & & \\
\hline $0.23 \pm 0.04$ & $1.49 \pm 0.13(7)$ & (12) & $0 \cdot 0$ \\
\hline 0.0 & $0.37 \pm 0.41(3)$ & 0.0 & ND \\
\hline (1) & ND & ND & ND \\
\hline
\end{tabular}

ND, Not determined.

* Mean \pm standard deviation, with the number of experiments in parentheses.

$\dagger$ Maximal bacterial concentrations in these conditions were very low in spite of the relatively high specific growth rates.

$\ddagger$ Growth at these temperatures was erratic, occurring in some experiments but not in others. 

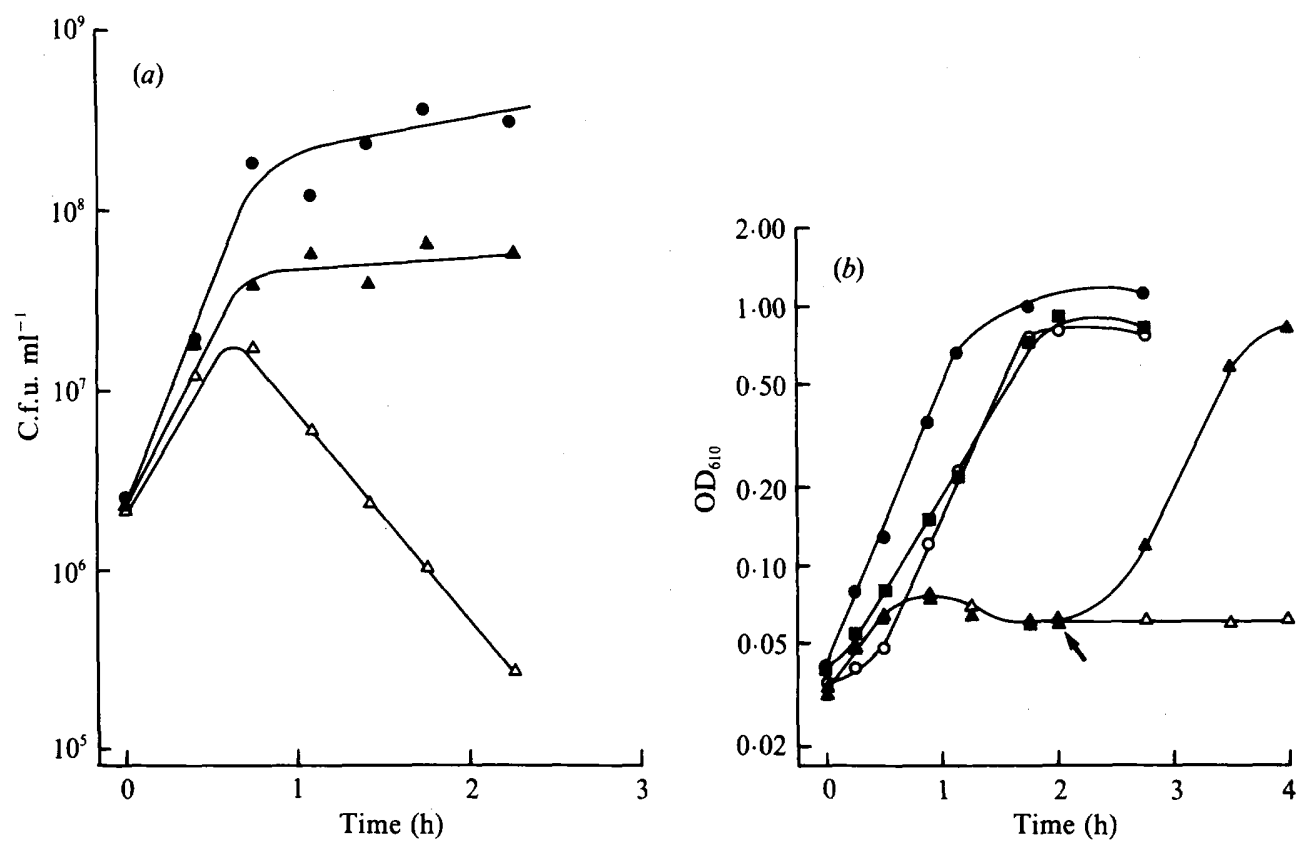

Fig. 3. Effect of $\mathrm{Sr}^{2+}$ on the growth of B. stearothermophilus. (a) Growth (determined as c.f.u.) of cultures grown at $60^{\circ} \mathrm{C}$ in media containing $2.5 \mathrm{mM}-\mathrm{Ca}^{2+}(O), 2.5 \mathrm{mM}^{2} \mathrm{Sr}^{2+}(\Delta)$ and $10 \mathrm{mM}-\mathrm{Sr}^{2+}(\triangle) .(b)$ Reversal of the inhibition by $\mathrm{Sr}^{2+}$ was determined by adding $2.5 \mathrm{~mm}-\mathrm{Ca}^{2+}$ (arrow) to a culture grown in medium containing $10 \mathrm{mM}-\mathrm{Sr}^{2+}$ at $68^{\circ} \mathrm{C}(\mathrm{A})$. Growth was also monitored in control medium (O), and media containing $10 \mathrm{mM}-\mathrm{Ca}^{2+}(O), 10 \mathrm{mM}-\mathrm{Mg}^{2+}(\square)$ and $10 \mathrm{mM}-\mathrm{Sr}^{2+}(\triangle)$. The results shown are typical of those obtained in two separate experiments.

\section{Formation of abnormal cells in $\mathrm{Sr}^{2+}$-containing medium}

Phase-contrast and electron microscopy revealed morphological alterations in cells of $B$. stearothermophilus grown in media containing $2.5 \mathrm{mM}$ - and $10 \mathrm{mM}-\mathrm{Sr}^{2+}$. Bacteria were stained with crystal violet and measurements of 50 representative cells were made using a stage micrometer. Early stationary phase cells at $60^{\circ} \mathrm{C}$ derived from medium containing $2.5 \mathrm{~mm}-\mathrm{Ca}^{2+}$ were $2.24 \pm 0.95 \mu \mathrm{m}$ long and $0.48 \pm 0.05 \mu \mathrm{m}$ wide. The addition of $2.5 \mathrm{~mm}-\mathrm{Sr}^{2+}$ instead of $\mathrm{Ca}^{2+}$ resulted in the formation of slightly abnormal cells in which the major difference detected by phase-contrast microscopy was an increase in the cell width to $1.02 \pm 0 \cdot 13 \mu \mathrm{m}$. Much larger cells, $6.05 \pm 1.92 \mu \mathrm{m}$ long and $1.61 \pm 0.45 \mu \mathrm{m}$ wide, were observed in cultures containing $10 \mathrm{~mm}$ $\mathrm{Sr}^{2+}$. These cells also displayed aberrant shapes, contrasting with the regular rod-shaped cells grown in control medium or media containing added $\mathrm{Ca}^{2+}$ or $\mathrm{Mg}^{2+} . \mathrm{Sr}^{2+}$-inhibited cultures also contained cells undergoing lysis and abundant cellular debris. Formation of abnormal cells in cation-inhibited cultures was induced only by $\mathrm{Sr}^{2+}$ : growth inhibition by $10 \mathrm{mM}-\mathrm{Mg}^{2+}$ did not induce abnormal morphologies. Electron microscopy of the $\mathrm{Sr}^{2+}$-inhibited cells showed incomplete septa and enlargement of the cell dimensions, but the cell wall retained the thickness characteristic of cells grown in control medium or media containing added $\mathrm{Ca}^{2+}$ (Fig. 4).

\section{DISCUSSION}

Earlier investigations have shown that divalent cations are required for thermophilic growth (Ljunger, 1970; Stähl \& Ljunger, 1976; Stähl, 1978). The growth dependence of the mesophile Escherichia coli on divalent cations has also been reported (Arancia et al., 1980): when divalent cations were limiting, the lag periods and doubling times were longer and the final bacterial concentrations were lower than in medium supplemented with $1 \mathrm{mM}-\mathrm{Mg}^{2+}$; a sharp fall in viable 

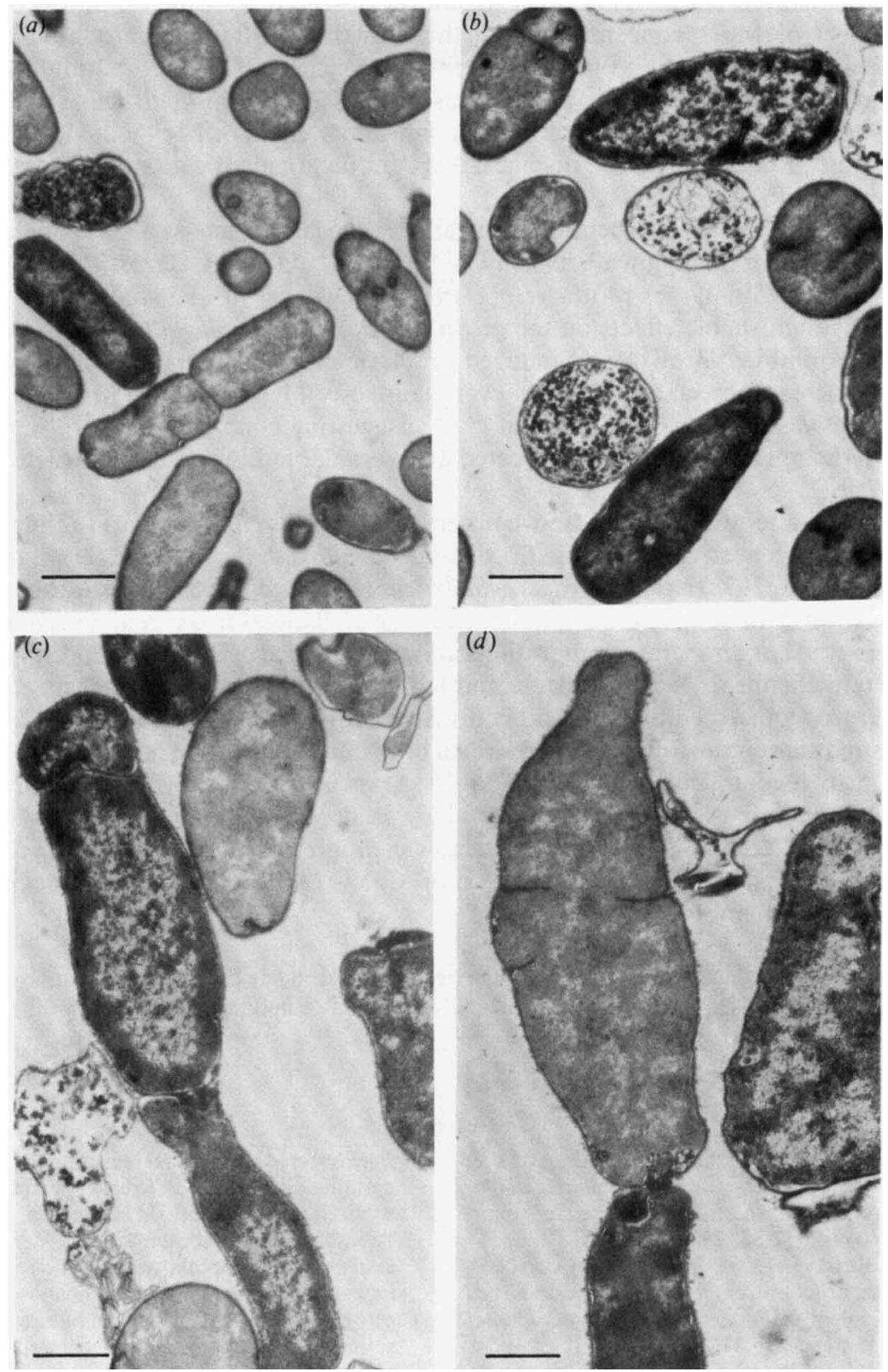

Fig. 4. Electron micrographs of $B$. stearothermophilus from early stationary phase cultures at $65^{\circ} \mathrm{C}:(a)$ in medium containing $2.5 \mathrm{mM}-\mathrm{Ca}^{2+},(b)$ in medium containing $2.5 \mathrm{mM}-\mathrm{Sr}^{2+}$ and $(c, d)$ in medium containing $10 \mathrm{mM}-\mathrm{Sr}^{2+}$. Bars, $1 \mu \mathrm{m}$.

counts was also observed at the end of the exponential growth phase. Our results with $B$. stearothermophilus are essentially consistent with these earlier observations. Thus, $\mathrm{Ca}^{2+}$ improved growth at supraoptimal temperatures, inducing higher specific growth rates, higher bacterial yields and shorter lag phases. Furthermore, $\mathrm{Ca}^{2+}$ extended the range of the maximal temperature for growth.

The effect of $\mathrm{Mg}^{2+}$ on the growth of $B$. stearothermophilus differed significantly from that of $\mathrm{Ca}^{2+}$ in that $10 \mathrm{mM}-\mathrm{Mg}^{2+}$, in contrast to $2.5 \mathrm{mM}-\mathrm{Mg}^{2+}$ (which was stimulatory), inhibited growth 
at supraoptimal temperatures. This effect was never observed with the same concentration of $\mathrm{Ca}^{2+}$. An effect of $\mathrm{Mg}^{2+}$ concentration on the growth of different mesophilic bacteria in complex media was observed by Webb (1966): at low concentrations, $\mathbf{M g}^{2+}$ stimulated growth, but above a critical concentration, growth was progressively inhibited. Our studies with $B$. stearothermophilus additionally showed that the inhibitory effect of $\mathrm{Mg}^{2+}$ could be reversed by addition of $\mathrm{Ca}^{2+}$. Presumably $\mathrm{Ca}^{2+}$ displaces $\mathrm{Mg}^{2+}$ at the divalent cation interaction sites and thus relieves the inhibitory effect.

$\mathrm{Sr}^{2+}$ is commonly believed to behave in certain biological systems as a $\mathrm{Ca}^{2+}$ analogue; thus, calcium pumps do not distinguish between $\mathrm{Ca}^{2+}$ and $\mathrm{Sr}^{2+}$ (Olson \& Cazort, 1969; Mermier \& Hasselbach, 1976; Guimarães-Motta et al., 1984). However, in our studies $\mathrm{Sr}^{2+}$ and $\mathrm{Ca}^{2+}$ had readily distinguishable effects on the growth of $B$. stearothermophilus. $\mathrm{Sr}^{2+}$, in contrast to $\mathrm{Ca}^{2+}$, strongly inhibited growth and induced dramatic changes in cell morphology including uncontrolled increase in cell size, leading eventually to cell lysis. As with $\mathbf{M g}^{2+}$, inhibition of growth by $\mathrm{Sr}^{2+}$ was relieved by addition of $\mathrm{Ca}^{2+}$, suggesting competition of $\mathrm{Sr}^{2+}$ and $\mathrm{Ca}^{2+}$ for the same interaction sites, presumably located at external, readily accessible structures such as the membrane.

Morphological alterations like those we observed in B. stearothermophilus in the presence of $>2.5 \mathrm{mM}^{-\mathrm{Sr}^{2+}}$ have been described in E. coli and Bacillus subtilis mutants (Long et al., 1978; Rogers \& Thurman, 1978) and in Bacillus caldolyticus (Aart et al., 1981). These alterations were believed to reflect various environmental stresses such as changes in oxygen, nitrogen or glucose concentrations, $\mathrm{pH}$ or temperature alterations and the presence of drugs (6-amidinopenicillanic acid) or certain chemicals, such as nitrate and halides (Long et al., 1978; Rogers \& Thurman, 1978). E. coli grown in a medium deficient in divalent cations showed structural modifications in the cytoplasmic membrane following a presumed lipid phase transition, not observed in bacteria grown in control medium containing $1 \mathrm{mM}-\mathrm{Mg}^{2+}$ (Arancia et al., 1980). The structural integrity of protoplast membranes of $B$. stearothermophilus was also shown to be maintained by divalent cations (Wisdom \& Welker, 1973). Studies are now in progress with liposomes and protoplasts of B. stearothermophilus to ascertain the effect of $\mathrm{Ca}^{2+}, \mathrm{Mg}^{2+}$ and $\mathrm{Sr}^{2+}$ on the biophysical properties of their membranes.

This work was supported in part by a grant from the Instituto Nacional de Investigação Científica (INIC). The authors also wish to thank Professor M. Teixeira da Silva for many helpful comments concerning the electron microscopy.

\section{REFERENCES}

Aart, P. H. M., Heinen, U. J., Lauwers, A. M. \& HeINEN, W. (1981). Versatility of Bacillus caldolyticus with regard to thermoadaptation and morphology. Mikroskopie 38, 265-277.

Arancia, G., Belli, S., Donelli, G. \& Trovalusci, P. (1980). Ultrastructural changes in Escherichia coli grown in divalent cation-deficient medium. Journal of General Microbiology 119, 155-164.

Brock, T. D. (1967). Life at high temperatures. Science 158, 1012-1019.

Daron, H. H. (1970). Fatty acid composition of lipid extracts of a thermophilic Bacillus species. Journal of Bacteriology 101, 145-151.

Friedman, S. M. (1968). Protein-synthesizing machinery of thermophilic bacteria. Bacteriological Reviews 32, 27-38.

Guimarães-Motta, H., Sande-Lemos, M. P. \& DE MEIS, L. (1984). Energy interconversion in sarcoplasmic reticulum vesicles in the presence of $\mathrm{Ca}^{2+}$ and $\mathrm{Sr}^{2+}$ gradients. Journal of Biological Chemistry 259, 8699-8705.

Hasegawa, Y., Kawada, N. \& Nosoh, Y. (1980). Change in chemical composition of membrane of
Bacillus caldotenax after shifting the growth temperature. Archives of Microbiology 126, 103-108.

IRWin, C. C., AkaGi, J. M. \& Himes, R. H. (1973). Ribosomes, polyribosomes and deoxyribonucleic acid from thermophilic, mesophilic and psychrophilic clostridia. Journal of Bacteriology 113, 252-262.

LJUNGER, C. (1970). On the nature of the heat resistance of thermophilic bacteria. Physiologia plantarum 23, 351-364.

LonG, W. S., Slayman, C. L. \& Low, K. B. (1978). Production of giant cells of Escherichia coli. Journal of Bacteriology 133, 995-1007.

Mermier, P. \& Hasselbach, W. (1976). Comparison between strontium and calcium uptake by the fragmented sarcoplasmic reticulum. European Journal of Biochemistry 69, 79-86.

Mosley, G. A., CARD, G. L. \& Koostra, W. L. (1976). Effect of calcium and anaerobiosis on the thermostability of Bacillus stearothermophilus. Canadian Journal of Microbiology 22, 468-474.

Olson, E. J. \& CAZORT, R. J. (1969). Active calcium and strontium transport in human erythrocyte ghosts. Journal of General Physiology 53, 311-322. 
RAY, P. H., WhIte, D. C. \& Brock, T. D. (1971 a). Effect of temperature on the fatty acid composition of Thermus aquaticus. Journal of Bacteriology 106, 2530.

RAY, P. H., White, D. C. \& BRock, T. D. (1971b). Effect of growth temperature on the lipid composition of Thermus aquaticus. Journal of Bacteriology 108, 227-235.

Rogers, H. J. \& Thurman, P. F. (1978). Temperaturesensitive nature of the rodB mutation in Bacillus subtilis. Journal of Bacteriology 133, 298-305.

RYTER, A. \& Kellenberger, E. (1958). Étude au microscope électronique de plasmas contenant de l'acide désoxyribonucléique. Zeitschrift für Naturforschung 13b, 597-605.

Silva, M. T. (1984). The use of transmission electron microscopy of ultrathin sections for the characterization of the ultrastructure of normal and damaged bacterial membranes. In Biomembranes: Dynamics and Biology, pp. 1-36. Edited by R. M. Burton \& F. C. Guerra. NATO ASI series A, Life Sciences, vol. 76. New York: Plenum Press.

Singleton, R. \& AmelunXen, R. E. (1973). Proteins from thermophilic microorganisms. Bacteriological Reviews 37, 320-342.
STÄHL, S. (1978). Calcium uptake by Bacillus megaterium variants grown at $10^{\circ} \mathrm{C}$ to $65^{\circ} \mathrm{C}$. FEMS Microbiology Letters 4, 77-81.

STÄHL, S. \& LJUNGER, C. (1976). Calcium uptake by Bacillus stearothermophilus: a requirement for thermophilic growth. FEBS Letters 63, 184-187.

Venable, J. H. \& Coggeshall, R. (1965). A simplified lead citrate stain for use in electron microscopy. Journal of Cell Biology 25, 407-408.

WEBB, M. (1966). The utilization of magnesium by certain Gram-positive and Gram-negative bacteria. Journal of General Microbiology 43, 401-409.

WeErKamp, A. \& HeINEN, W. (1972). Effect of temperature on the fatty acid composition of the extreme thermophiles, Bacillus caldolyticus and Bacillus caldotenax. Journal of Bacteriology 109, 443446.

Wisdom, C. \& Welker, N. E. (1973). Membranes of Bacillus stearothermophilus: factors affecting protoplast stability and thermostability of alkaline phosphatase and reduced nicotinamide adenine dinucleotide oxidase. Journal of Bacteriology 114, $1336-1345$. 